Ann. Biol. anim. Bioch. Biophys., I972, 12 (2), 321-328.

\title{
CONCENTRATION OF NUCLEI IN CHICKEN MUSGLE FIBRE IN RELATION TO THE INTENSITY OF GROWTH
}

\author{
Helena KNfŽETOVÁ, B. KNIŽE, V. KOPEČNÝ and J. FULKA \\ Department of Genetics, Faculty of Science, Charles University, \\ Vinična 5, Prague (Czechoslovakia) \\ Laboratory of Animal Genetics, \\ Czechoslovak Academy of Sciences, Liběchov (Czechoslovakia)
}

\section{SUMMARY}

In chickens sharply differing in growth intensity, the nuclear concentration on a constant length segment of muscle fibre released by maceration has been investigated. At the same time DNA concentration in muscular tissue and the frequency of ${ }^{3} \mathrm{H}$-thymidine labelled nuclei in the individual groups have been examined.

The content of nuclear component converted to volume unit of the fibre decreased in the course of the investigated period. The lowest values of this nucleo-plasmatic ratio were found in chickens with the highest intensity of growth. The tendency of changes in DNA concentration of the muscle tissue are in approximate agreement with these observations.

In the course of the investigated period a decline in the frequency of ${ }^{3} \mathrm{H}$-thymidine labelled nuclei has been observed. Differences in the share of labelled nuclei positively corresponding to the intensity of growth in the individual groups appear only in 7-day old chickens. The hypothesis is suggested that during the period of low proliferation level there may exist local differences of incorporation frequency in the muscle.

\section{INTRODUC'TION}

One of the basic problems of skeletal muscle growth is the mechanism of muscle fibre nuclei multiplication and the changes in their concentration during postnatal development. The opinion prevailing at present is that the so-called satellite cells are responsible for the fibre nuclear component increase. Mitotic division takes place in these cells which are evenly distributed between the basal and inner membranes of the muscular fibres, and their nuclei are incorporated into the fibres 
themselves (Mauro. I961 ; MUIR, Kanji and Allbrook, I965; RezNiK, I969; Moss and LEBL,OND, I97I).

During muscular growth, the general feature appears to be a decrease of nuclear concentration. This fact has been demonstrated in different animal species by means of two methods : $\mathrm{r}^{\circ}$ histoplanimetric method, revealing the ratio between the nuclear and cytoplasmatic fibre component on sections prepared by the usual histological technique (Davydova and Voloshik, I962; Dmitrieva, I965), $2^{\circ}$ indirect determination on the basis of concentration changes in DNA (ENESCO and LEBLOND, I962; ENEsco and Puddy, I964; Moss, Srmmonds and McNary, I964). The relative decrease of the nuclear component in muscular tissue of chickens has been also confirmed by data indicating changes in labelling indices after ${ }^{3} \mathrm{H}$-thymidine application (Marchok and Herrmann, ig67; Mitroiv, Lang and Maurer, ig68). Some of the above-mentioned authors and also WinNick and NoBLE (r965) and Mizuno, HIKAMI and Sumito (I 966 ) consider the changes of DNA concentration during development in relation to the increase of the cytoplasmatic component of the fibres, i.e. muscle proteins.

The aim of the present investigation was to compare the changes of nuclear concentration in muscle fibres in groups of chickens sharply differing in growth intensity, final body weight, and thus also in mean diameter of muscle fibre. Contrary to previous authors, the nuclear content was investigated by direct determination of the number of nuclei on constant length of isolated muscle fibre released by maceration (fig. I). The advantage of this method is that the nuclei of the muscle fibres may be reliably detected. The differences found were compared with the values obtained from muscular DNA determination. Besides this, the frequency of nuclei labelled with ${ }^{8} \mathrm{H}$-thymidine has been investigated in the individual groups of chickens.

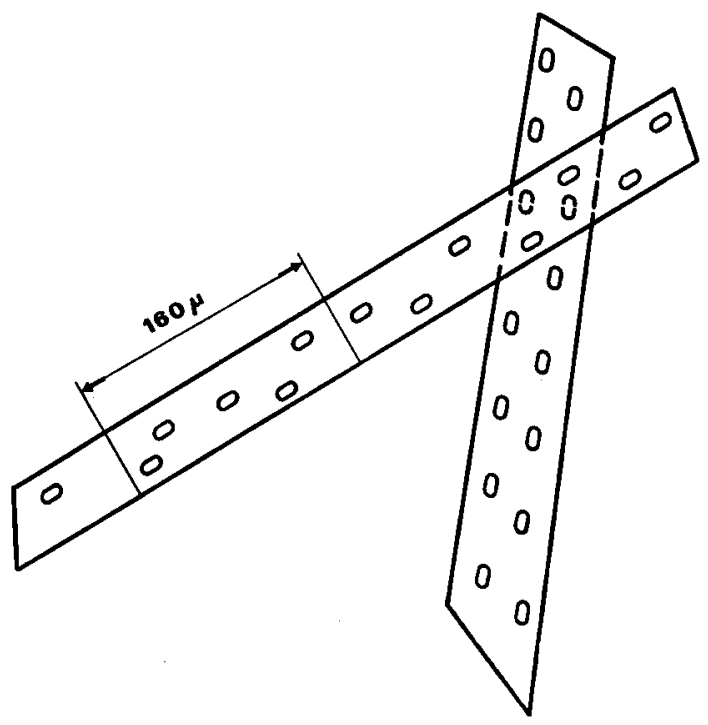

Fig. I

The determination of the number of nuclei in isolated muscle fibre 


\section{MATERIAL AND METHODS}

Three groups, each consisting of thirty chickens, were included in this experiment : New Hampshire (NH), Rose Comb Bantam $(R C B)$ and their $\mathrm{F}_{1}$ crosses $\left(0^{*} R C B \times \% N H\right)$. At the age of 2,4 and $\mathrm{r} 2$ weeks resp., ten chickens from each group were killed and used for the experimental procedure described below. Characteristics of the experimental material are given in table $\mathrm{r}$.

TABLE I

Average live weight $(\mathrm{g})$ and diameter of muscle fibres $(\mu)$

Poids vif moyen $(\mathrm{g})$ et diamètre de la fibre musculaive $(\mu)$

\begin{tabular}{|c|c|c|c|c|}
\hline \multirow{2}{*}{ Groups } & \multicolumn{2}{|c|}{ Live weight } & \multicolumn{2}{|c|}{ Diameter of fibres } \\
\hline & 1 day & 200 days & 1 day & 200 days \\
\hline $\begin{array}{l}N H \ldots \ldots \\
R C B \times \dot{N H} \ldots \ldots \\
R C B \ldots\end{array}$ & $\begin{array}{l}40.2 \pm 0.64 \\
39.7 \pm 0.96 \\
28.5 \pm 0.48\end{array}$ & $\begin{array}{r}2399 \pm 15.2 \\
1414 \pm 61.7 \\
654 \pm 23.6\end{array}$ & $\begin{array}{l}4.514 \pm 0.20 \\
4.57 \pm 0.12 \\
3.73 \pm 0.31\end{array}$ & $\begin{array}{l}50.6 \pm 4.11 \\
38.4 \pm 2.47 \\
24.2 \pm 2.37\end{array}$ \\
\hline
\end{tabular}

The determination of nuclear concentration in muscle fibres was performed on samples from the breast muscle (m. pectoralis major). The material was fixed in a mixture of $96 \mathrm{p}$. cent alcohol and glacial acetic acid $(3: \mathrm{I})$ for ten minutes. The samples were then rinsed in $70 \mathrm{p}$. cent alcohol and kept in this solution until further use. Prior to separation, a maceration mixture of glycerine and water $(\mathrm{I}: \mathrm{I})$ was used for the isolation of individual muscle fibres which were finally stained with acetocarmine. The number of nuclei determined on a constant length of isolated muscle fibre $(I 6 \circ \mu)$ was converted with respect to the individual diameter to the so-called index of nucleo-plasmatic ratio (N/P) to $10^{6} \mu^{3}$ of the fibre volume.

The determination of DNA in the muscle samples was carried out spectrophotometrically according to the method of Schneider, modified by CERIOTTI (1952). The individual DNA values obtained from the calibration curve at the extent of $5-15 \mu / \mathrm{ml}$ were converted to $\mathrm{mg} \mathrm{p}$. cent of fresh tissue. Three samples were evaluated for each animal.

${ }^{3} \mathrm{H}$-thymidine incorporation was investigated in another group of chickens at the age of 7 and 28 days. This precursor was injected intravenously $90 \mathrm{~min}$ before sacrificing the animal in the morning (ro-12 a. m.). 7-day old chickens were injected with thymidine-methyl- ${ }^{-3} \mathrm{H}$, spec. activity $9.0 \mathrm{Ci} / \mathrm{mmol}$, at a dose of $2 \mu \mathrm{Ci}$ per gramme body weight. 28-day old chickens were treated with thymidine- $6-{ }^{3} \mathrm{H}$, spec. activity $25.58 \mathrm{Ci} / \mathrm{mmol}$, at a dose of $\mathrm{I} \mu \mathrm{Ci}$ per I gramme body weight. Both precursors were supplied by ÚvvvR, Prague.

Samples from the middle segment of $\mathrm{m}$. pectoralis major were Carnoy fixed, sectioned lengthwise at $4 \mu$, coated with liquid emulsion Ilford $L_{4}$, exposed for 78 days and haematoxylin-eosin stained. About 5 ooo nuclei were evaluated in each section and those with more than 15 grains were considered as labelled. All differences were verified by means of the $t$-test.

\section{RESULTS}

\section{The number of nuclei in muscle fibres}

As may be seen from table I, our material was selected so that it allowed the comparison of changes in nuclear concentration in groups differing in the mean diameter of muscle fibres. These differences are the expression of a close relationship 
between the average thickness of the fibres and the growth intensity of the animals.

From the results given in table 2 it may be concluded that the mean number of nuclei on a constant length of muscle fibre increases during the investigated period of postnatal growth. This increase becomes markedly evident at the age of 4-r2 weeks only, $i . e$. during the period when a more substantial enlargement in the fibres takes

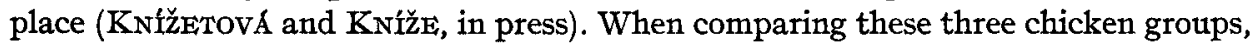
different values $(\mathrm{P}<0$.oI $)$ may be observed. These are parallel to the order of the average fibre diameter.

TABI,E 2

Average number of nuclei on constant length ( $160 \mu$ ) of muscle fibres Nombre moyen de noyaux sur un segment constant ( $160 \mu)$ de la fibre musculaire

\begin{tabular}{c|c|c|c}
\hline \hline \multicolumn{1}{c|}{ Groups } & 2 weeks & 4 weeks & 12 weeks \\
& & & \\
& & & \\
$N H \ldots \ldots \ldots$ & $7.86 \pm 0.254$ & $8.70 \pm 0.469$ & $20.77 \pm 0.484$ \\
$R C B \times N H \ldots$ & $8.32 \pm 0.280$ & $9.38 \pm 0.359$ & $17.23 \pm 0.727$ \\
$R C B \ldots \ldots \ldots$ & $6.86 \pm 0.274$ & $7.78 \pm 0.115$ & $16.16 \pm 0.581$ \\
\hline
\end{tabular}

\section{TABLE 3}

Average concentration of nuclei in muscle fibres (in $10^{4} \cdot \mu^{3}$ of individual fibre) Concentration moyenne de noyaux dans les fibres musculaires (dans $10^{6} \cdot \mu^{3}$ de fibre)

\begin{tabular}{|c|c|c|c|}
\hline Groups & 2 weeks & 4 weeks & 12 weeks \\
\hline$N H \ldots \ldots$ & $77.2 \pm 6.52$ & $72.6 \pm 3.31$ & $40.1 \pm 2.28$ \\
\hline$R C B \times N H \ldots$ & $92.5 \pm 13.62$ & $87.4 \pm 2.68$ & $42.2 \pm 3.08$ \\
\hline$R C B \ldots \ldots$ & $176.6 \pm 12.45$ & $163.2 \pm 26.05$ & $61.6 \pm 2.71$ \\
\hline
\end{tabular}

TABLE 4

Concentration of DNA in muscle tissue (mg p. cent) Concentration d'ADN dans le tissu musculaire (mg p. cent)

\begin{tabular}{|c|c|c|c|}
\hline Groups & 10 days & 28 days & 85 days \\
\hline$N H \ldots \ldots \ldots$ & $127.2 \pm 5.67$ & $81.1 \pm 2.61$ & $45.9 \pm 1.16$ \\
\hline$R C B \times N H \ldots$ & $132.8 \pm 8.52$ & $82.8 \pm \mathbf{5 . 0 8}$ & \\
\hline$R C B \ldots \ldots$ & $157.6 \pm 8.24$ & $89.3 \pm 10.55$ & $52.9 \pm 0.69$ \\
\hline
\end{tabular}


The number of nuclei found on a certain length of muscle fibre and converted into volume unit illustrates the nucleoplasmatic ratio of elements in the muscle tissue. The results in table 3 show that the values of this $N / P$ ratio decrease during the investigated period of postnatal development, $i . e .$, the amount of cytoplasm per one nucleus gradually increases. This tendency appears to be more expressive in animals of the most intensively growing group. A similar situation can be observed also in the case of DNA concentration (table 4). Significantly lowest values were found in all three investigated intervals of the $\mathrm{NH}$ group.

\section{The proliferation of nuclei}

The data given in table 5 suggest that the frequency of ${ }^{3} \mathrm{H}$-thymidine labelled nuclei decreases during the investigated period. The mean frequency values in 7-day old chickens in all the three groups range from 2.Ir-4.37 p. cent, whereas at the age of 28 days they drop to I.7I-I.96 p. cent. If we consider frequency changes in

TABLE 5

Weight of chickens ( $\mathrm{g}$ ) and labelling frequency (p. cent) of nuclei

Poids des poulets ( $\mathrm{g}$ ) et fréquence de marquage (p. cent) des noyaux

\begin{tabular}{|c|c|c|c|c|}
\hline \multirow{2}{*}{ Groups } & \multicolumn{2}{|c|}{7 days } & \multicolumn{2}{|c|}{28 days } \\
\hline & weight & $\%$ & weight & $\%$ \\
\hline$N H$ & 54 & 4.37 & 347 & 1.96 \\
\hline$R C B \times N H$ & 51 & 3.42 & 259 & 1.79 \\
\hline$R C B \ldots \ldots$ & 33 & 2.11 & 105 & 1.71 \\
\hline
\end{tabular}

connection with the considerable growth intensity of skeletal musculature, this fact, too, confirms indirectly the finding that nuclear concentration in muscle fibres decreases in the course of ontogenesis. If we compare the frequency of nuclei which incorporated ${ }^{3} \mathrm{H}$-thymidine in the different groups, a significant parallelism with growth can be observed only in the 7 -day old chickens $(P<0.05)$. The highest mean valul can be noted in intensively growing $N H$ chickens, the lowest in $R C B$ and an intermediary value in their crosses. Four-week old animals do not exhibit differences in the frequency values of labelled nuclei without respect to considerable differences in body weight and intensity of growth $(\mathrm{P}>0.05)$.

\section{DISCUSSION}

In the literature the opinion prevails that skeletal muscles gain during postembryonic stage mainly through fibre hypertrophy, i.e. the enlargement of individual elements. The possibility of hyperplasy, $i . e$. the increase in the number of fibres is 
considered less important (JouBERT, I956, I958 ; SMITH, I963; STAUN, I963). In this connection arises the question concerning nuclear component changes in the muscle tissue. According to many authors, the number of nuclei increases at a certain proportion to the growth of muscles and the enlargement of the fibre diameter. This fact has been demonstrated mainly by the determination of DNA in the tissue sample, allowing for the gross weight of the muscle and the DNA content in the individual diploid nuclei (ROBINSON, I952; ENESCO and LEBLOND, I962 ; ENESCO and Puddy, r964; Moss, Simmonds and McNary, I964; Hrkami and Mizuno, I965). The authors report an increase of nuclear component of muscle elements which corresponds partly to muscle growth. They emphasize at the same time that the increment in the quantity of nuclei and plasmatic component does not take place with the same intensity. It seems that the quicker growth of the plasmatic component has a more persisting tendency especially in the postnatal life so that the amount of cytoplasm per nucleus increases gradually. The results of our experiments, where the determination of number and concentration of nuclei was performed directly on isolated muscle fibres, confirm these changes (table 2 and 3). Moreover, when comparing the chicken groups with different growth intensity it was found that there is a parallelism between the number of nuclei and the diameter of fibres. Considering the relative values, on the other hand, $i$. $e$. the $\mathrm{N} / \mathrm{P}$ ratio, it is evident that nuclear concentration is the lowest in chickens with intensive growth. In approximate agreement with this tendency are also the data on DNA concentration (table 4). It seems that at the more advanced stage of development the lower values of the $\mathrm{N} / \mathrm{P}$ ratio and lower DNA level in intensively growing chickens may be attributed to higher values of cytoplasm fibre component increase. It is however difficult so far to explain'the marked differences of these items in the 2-week old chicken group where the distinctions of fibre diameters are not yet so expressive. The causes for these differences may be probably found in the period of myoblast fusion and the myotube formation.

When analysing the changes of nuclear concentration in muscle tissue we are bound to encounter the problem of DNA synthesis and proliferation activity of nuclei. In detailed studies Moss and L,EBLOND (I97I) proved that the satellite cells localized between plasmolemma and basement membrane of the muscle fibre are the source of the nuclei. The authors found that in rats of $30 \mathrm{~g}$ body weight roughly $2.5 \mathrm{p}$. cent of nuclei is daily incorporated in the fibres. In the chickens, data relating to this question are scarce. MARCHOK and HERRMANN (I967) investigated proliferation intensity of nuclei in the DNA synthetic phase of chickens from the 7 th day of embryonic development until the 8th day after birth. The authors found that during the mentioned period the frequency of ${ }^{\circ} \mathrm{H}$-thymidine labelled nuclei decreased from 40 per cent to 0.8 per cent. Mrtroru, LANG and MAURER (I968) compared the labelling index of muscle nuclei in chickens during postnatal development. In twoday old animals they found an index of 4-6 per cent, at the age of 35 days only $0.05-0.25$ per cent. Compared with these data, the values of labelled nuclei frequency in our experiment are somewhat higher (table 5). If we consider the results of nuclear increase during the investigated period (table 2 ), the frequency values found in our experiment appear quite real. It follows from our findings that a certain decrease occurs in the frequency of nuclei at the S-phase during the investigated period. Considering this fact in connection with the intensive growth of muscle fibres, a 
tendency towards the increase of cytoplasm per nucleus during development can also be supported. The elimination of some differences in 28-day old chickens may evidently be attributed to a lower proportion of nuclei at the S-phase. However, the possibility cannot be excluded that there are certain local differences in the proliferation activity, especially in larger muscular complexes. KITIYAKARA and ANGEVINE (I963) presume ${ }^{3} \mathrm{H}$-thymidine incorporation into nuclei localized in the terminal sections of fibres.

Reçu pour publication en janvier 1972

\section{RÉSUMÉ́}

\section{NOMBRE DE NOYAUX DANS LES FIBRES MUSCULAIRES DU POULET EN FONCTION DE LA VITESSE DE CROISSANCE}

Chez des poulets différant par l'intensité de croissance, on a étudié le nombre de noyaux libérés par macération dans un segment constant des fibres musculaires. Dans les différents groupes on a simultanément tenu compte de la concentration en ADN dans le tissu musculaire et de la fréquence des noyaux marqués par la ${ }^{3} \mathrm{H}$-thymidine.

Le volume du constituant nucléaire, rapporté à l'unité volumétrique de fibre, a diminué au cours de la période d'investigation. On a trouvé les plus basses valeurs de cette relation nucléoplasmatique chez les poulets avec la plus grande intensité de croissance. La tendance des variations de la teneur en ADN du tissu musculaire est approximativement en harmonie avec cette observation.

Entre les deux âges étudiés, 7 et 28 jours, on a noté un abaissement de la fréquence des noyaux marqués par la ${ }^{3} \mathrm{H}$-thymidine. Les différences dans la proportion des noyaux marqués selon l'intensité de la croissance des différents groupes ne se sont manifestés que chez les poulets âgés de 7 jours. Quand la prolifération nucléaire devient faible, il est suggéré que se produisent des différences locales dans la fréquence des noyaux en phase de synthèse d'ADN.

\section{RÉFÉRENCES BIBLIOGRAPHIQUES}

Ceriotri G., I952. A microchemical determination of desoxyribonucleic acid. J. Biol. Chem., 198, 297-303.

Davydova Z. M., Voloshik P. D., I962. The changes of muscular tissue in swine of Murom breed in relationship with age and different types of feed. Doklady T.S. C. H. A., 85, 246-252 (in Russian).

DMitrieva M. M., I967. The changes of muscles in chickens of two different breeds. Diss. Abstr. Moscow (in Russian).

Enesco M., Leblond C. P., I962. Increase in cell number as a factor in the growth of the organs on tissues of the young male rats. J. Embr. Exp. Morphol., 10, 530-562.

Enesco M., Puddy D., I964. Increase in number of nuclei and weight in skeletal muscle of rats of various ages. Am. J. Anat., 114, 235-244.

Hikami Y., Mizuno T., r965. The effects of growth on the cell diameter, cell number and nucleic acid content of the skeletal muscles of chicks. Jap. J. Zootech. Sci., 86, 384-39o.

JoUBERT D. M., I956. An analysis of factors influencing postnatal growth and development of the muscle fibre. J. A gric. Sci., 47, 59-103.

Joubert D. M., I958. Wachstum der Muskelfaser vor und nach der Geburt. Zeitschr. Tierzucht, 71, 2I7-227.

Kitiyakara A., Angevine D. M., I963. A study of the pattern of postembryonic growth of m. gracilis in mice. Develop. Biol., 8, 322-340.

KNižETovi H., KNižE B. The changes of concentration of nuclei in fibres of skeletal muscle in chicken. Scientia A griculturae Bohemoslovaca (in the press). 
Marchok A. C., Herrmann H., I967. Studies of muscle development. I. Changes in cell proliferation. Develop. Biol., 15, I29-I 55.

Mauro A., r96r. Satellite cell of skeletal muscle fibres. J. Biophys. Biochem. Cytol., 9, 493-494.

Mitroiv P., LANG W., Maurer W., r968. Autoradiographische Bestimmung des Markierungsindex, des S-Phase und der Generationszeit einiger Zellarten von 2-35 Tage alten Kticken. Zeitschr. f. Zellforsch., 90, 68-80.

Mizuno T., Hikami Y., Sumito K., r966. The accumulation of nucleic acid and protein in the skeletal muscle of chicks during embryonic and postembryonic development. Jap. J. Zootech. Sci., 37, 471-477.

Moss F. P., LEBLond C. P., I97x. Satellite cells as the source of nuclei in muscles of growings rats. Amat. Rec., 170, $42 \mathrm{I} \cdot 436$.

Moss F. P., Simmonds R. A., McNary H. W., 1964. The growth and composition of skeletal muscle in the chicken. Poultry Sci., 43, 1086-109r.

Murr A. R., Kanji A. H., Allbrook D., r965. The structure of the satellite cells in skeletal muscle. J. Anat., 88, 435-444.

REzNik M., 1969. Thymidine ${ }^{3} \mathrm{H}$ uptake by satellite cells of regenerating skeletal muscle. J. Cell. Biol. 40, 568-57r.

RoBinson D. S., 1952. Changes in the nucleoprotein content of chick muscle during development. J. Biol. Chem., 52, 628-633.

Sмiтн J. A., 1963. Relation of body size to muscle cell size and number in the chicken. Poultry Sci, 42, $283-290$.

Staun H., 1963. Various factors affecting number and size of muscle fibre in the pig. Acta Agr. Scand., 13, $293-322$.

Winick M., NoBle A., 1965. Quantitative changes in DNA, RNA and protein during prenatal and postnatal growth in the rat. Develop. Biol., 12, 451-466. 